University of Nebraska - Lincoln

DigitalCommons@University of Nebraska - Lincoln

Papers in the Earth and Atmospheric Sciences

Earth and Atmospheric Sciences, Department

\title{
Evaluation of the streambed leakage concept in analytical models using data from three pumping tests
}

Sefan J. Kollet

Lawrence Livermore National Laboratory, kollet2@llnl.gov

Vitaly A. Zlotnik

University of Nebraska-Lincoln, vzlotnik1@unl.edu

Follow this and additional works at: https://digitalcommons.unl.edu/geosciencefacpub

Part of the Earth Sciences Commons

Kollet, Sefan J. and Zlotnik, Vitaly A., "Evaluation of the streambed leakage concept in analytical models using data from three pumping tests" (2007). Papers in the Earth and Atmospheric Sciences. 276.

https://digitalcommons.unl.edu/geosciencefacpub/276

This Article is brought to you for free and open access by the Earth and Atmospheric Sciences, Department of at DigitalCommons@University of Nebraska - Lincoln. It has been accepted for inclusion in Papers in the Earth and Atmospheric Sciences by an authorized administrator of DigitalCommons@University of Nebraska - Lincoln. 


\title{
Evaluation of the streambed leakage concept in analytical models using data from three pumping tests
}

\author{
Stefan J. Kollet • Vitaly A. Zlotnik
}

\begin{abstract}
Two-dimensional analytical models of pumping induced drawdown and stream depletion account for the streambed properties and stream geometry. Using data from three pumping tests performed under various hydrologic conditions, the following hypotheses were tested: (1) a partially penetrating stream at a certain distance from the pumping well can be represented by the streambed leakage term in the analytical models; (2) in the streambed leakage term, the streambed conductance coefficient $\lambda=\left(W K^{\prime}\right) / m^{\prime}$ accounts for the average stream width $W$, the streambed thickness $m^{\prime}$, and hydraulic conductivity $K^{\prime}$. The first hypothesis was tested by comparing results from tests under flow and no-flow stream conditions. The second hypothesis was tested by comparing results from two tests under low and high streamflow conditions. Similar estimates of the hydraulic conductivity and storativity for all tests indicate the validity of the streambed leakage term. The drawdown data of the test under low- and high-flow conditions (varying $W$ ) do not follow the predictions of the analytical models, which results in inconsistent $\lambda$ estimates. Thus, for different hydrologic conditions, $\lambda$ cannot be scaled solely by the stream width $W$. One possible explanation for this result is streambed dynamics caused by the changes in the stream stage.
\end{abstract}

Résumé Les rabattements dans les nappes et cours d'eau générés par des modèles analytiques de pompages en deux dimensions dépendent des propriétés du lit du cours d'eau considéré et de sa géométrie. En utilisant les données de

Received: 3 March 2006 / Accepted: 23 December 2006 Published online: 8 February 2007

(C) Springer-Verlag 2007

S. J. Kollet • V. A. Zlotnik

Department of Geosciences,

University of Nebraska,

Lincoln, 214 Bessey Hall, Lincoln, NE 68588, USA

Present address:

S. J. Kollet (『)

Environmental Science Division,

Lawrence Livermore National Laboratory (L-206),

7000 East Avenue, Livermore, CA 94550, USA

e-mail: kollet2@1lnl.gov

Tel.: +1-925-4229297

Fax: +1-925-4223118 trois essais de pompages effectués en conditions hydrologiques contrastées, les hypothèses suivantes ont été testées: (1) un ruisseau à pénétration partielle situé à une certaine distance du puits de pompage peut être exprimé par le terme de drainance dans les modèles analytiques; (2) dans le terme de drainance du lit du cours d'eau, le coefficient de conductivité du lit $\lambda=\left(W K^{\prime}\right) / m^{\prime}$ représente la largeur moyenne du cours d'eau $W$, l'épaisseur du lit $m^{\prime}$, et la perméabilité $K^{\prime}$. La première hypothèse a été testée en comparant les résultats des tests en conditions d'assèchement et d'écoulement. Pour éprouver la seconde hypothèse, les résultats de deux tests en conditions d'étiage et de hautes eaux ont été comparés. Sur l'ensemble des tests, la concordance entre les perméabilités calculées a permis de valider le terme de drainance du cours d'eau. Les rabattements observés en conditions d'étiage et de hautes eaux (W variable) ne suivent pas les prédictions des modèles analytiques, fournissant au final des estimations discordantes de $\lambda$. Aussi, dans le cas de conditions hydrologiques différentes, la seule largeur du cours d'eau ne suffit pas à estimer $\lambda$. Une explication possible de ce résultat réside dans la dynamique du lit causée par les variations de niveau du cours d'eau.

Resumen Modelos analíticos en dos dimensiones de descenso inducido por bombeo y de agotamiento de la corriente del río representan las propiedades del lecho del río y la geometría del mismo. Usando datos de tres ensayos de bombeo llevados a cabo bajo condiciones hidrológicas variadas, se probaron las siguientes hipótesis: (1) puede representarse un río parcialmente penetrante a una cierta distancia del pozo de bombeo por el término de goteo a través del lecho del río en los modelos analíticos; (2) en el término de goteo a través del lecho del río, el coeficiente de conductancia del lecho del río $\lambda=\left(W K^{\prime}\right) / \mathrm{m}^{\prime}$ representa el ancho promedio del río $W$, la potencia del lecho del río $m^{\prime}$, y la conductividad hidráulica $K^{\prime}$. La primera hipótesis fue comprobada comparando los resultados de pruebas bajo condiciones de flujo y no flujo de corriente. La segunda hipótesis fue probada comparando los resultados de dos pruebas bajo condiciones de corriente altas y bajas. Estimaciones similares de la conductividad hidráulica y el almacenamiento para todas las pruebas apuntan hacia la validez del término de goteo a través del lecho del río. Los datos de descensos de la prueba bajo condiciones de flujo altos y bajos (variando $W$ ) 
no siguen las predicciones de los modelos analíticos, lo que resulta en estimaciones inconsistentes de $\lambda$. Así, para condiciones hidrológicas diferentes, $\lambda$ no puede ser escalada solamente con el ancho de la corriente $W$. Una posible explicación para este resultado es la dinámica del lecho del río causada por los cambios en el nivel del río.

Keywords Groundwater/surface-water relations .

Hydraulic testing · Hydraulic properties .

Groundwater hydraulics

\section{Introduction}

Over the last decade, studies of groundwater-surface-water interactions in alluvial valleys have expanded to a broad variety of physical, chemical, and biological processes at various scales that range from a ripple in the stream channel to a watershed-e.g., Packman and Bencala (2000), Harvey and Wagner (2000), Woessner (2000), Kasahara and Wondzell (2003), Cardenas et al. (2004). These studies utilized laboratory, field, and modeling approaches to derive properties of the streambed. In spite of the recent progress in streambed characterization, the problem of in situ determination of the hydraulic conductivity distribution and alluvial architecture (delineation of the streambed) remains. Small-scale hydraulic testing and geophysics (Bierkens and Weerts 1994; Butler et al. 2002; Cardenas and Zlotnik 2003; Ritzi et al. 2004) can be used with upscaling to obtain these parameters at scales commensurate to modeling applications. However, these types of studies are labor-intensive and time-consuming and are, thus, limited to site scales of $10^{0}-10^{1} \mathrm{~m}$.

The conductance concept, where an average streambed thickness and hydraulic conductivity is used, is widely accepted in large-scale models of stream-aquifer interactions (Anderson and Woessner 1992). Therefore, it is appealing to utilize this concept implemented in commonly applied modeling tools-e.g., MODFLOW, McDonald and Harbaugh (1996) - as an alternative to detailed streambed characterization in the following context. Models that explicitly incorporate the streambed thickness $m^{\prime}$, average hydraulic conductivity $K^{\prime}$, and stream width $W$, are used for parameter identification via inverse modeling. This identification yields "apparent" parameter estimates that control integral large-scale fluxes across the stream-aquifer interface. The choice between analytical and numerical models for this approach depends on the complexity of the hydrogeologic conditions and availability of field data. In many situations, with relatively scarce field data and simple site geometry, analytical models may be appropriate.

In applications, analytical models for simulating stream depletion are of paramount interest. These models were designed to evaluate effects of groundwater abstraction on stream runoff in alluvial aquifers (see a brief review by Zlotnik 2004). Streambed properties are among the major factors controlling the seepage magnitude across the channel bed. Because aquifer drawdown and water losses from the stream can be used to identify the streambed properties, pumping test data including drawdown in multiple piezometers and flow and stage data from stream-gauging stations are needed.

In natural streams, streamflow discharge measurements and seepage meters have been applied with limited success due to relatively large measurement errors (Kaleris 1986; Sophocleous et al. 1988; Nyholm et al. 2003). Typically, the accuracy in stream discharge measurements is stated to be on the order of $5-10 \%$ of the actual streamflows (Hirsch and Costa 2004). To detect the effect of a well pumping at a constant rate of $6,000 \mathrm{~m}^{3} /$ day, the average seepage rate across the streambed has to be significantly larger than $10 \%$ of the actual stream discharge. Therefore, applications of this approach are limited to the streams with discharges smaller than $1.4 \mathrm{~m}^{3} / \mathrm{s}$ under the assumption that $100 \%$ of the pumped water originates from the stream, which might not be the case. Because accurate discharge data can be obtained in special situations only (e.g., Hunt et al. 2001; Nyholm et al. 2002), this study is limited to drawdown data analysis. For example, in the study presented here, the pumping tests were performed with a constant rate of $6,480 \mathrm{~m}^{3} /$ day. For the pumping test under low streamflow conditions, stream depletion rates were estimated to range from 20 to $50 \%$ of the pumping rate after 6 days of pumping (Kollet and Zlotnik 2003), which corresponds to $7-17 \%$ of the stream discharge (Fig. 1). Thus, it would not be feasible with the current technology to detect objectively the effect of pumping on discharge of the Prairie Creek, Nebraska, USA (Fig. 2) using direct measurements.

Three-dimensional analytical models of pumping tests near a stream are not available yet. Early two-dimensional

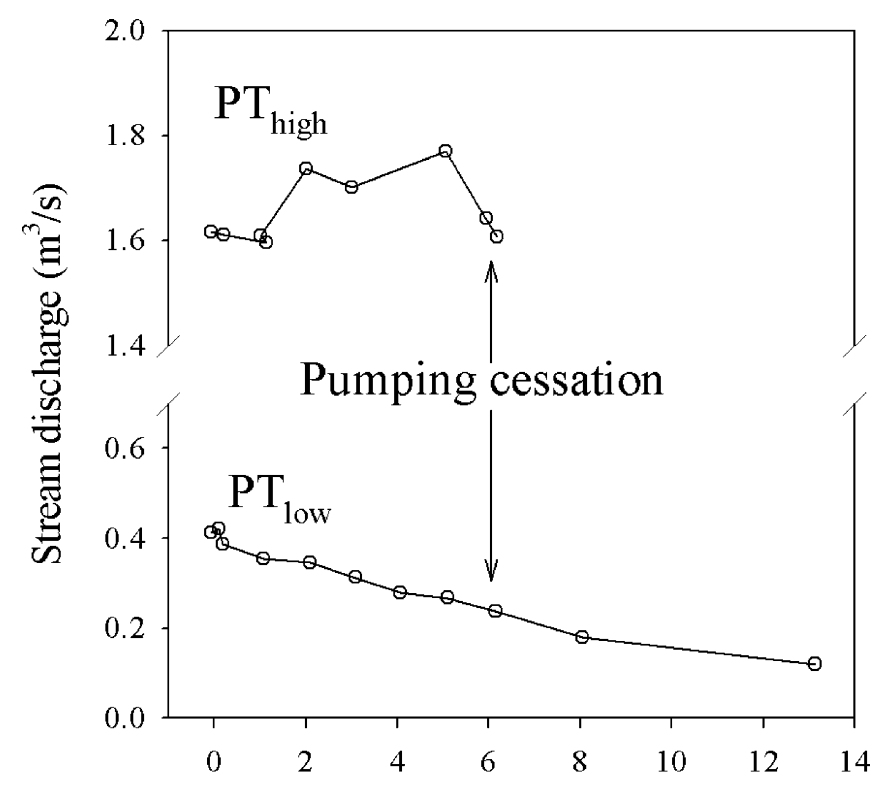

Time from start of pumping (days)

Fig. 1 Stream discharge during the pumping tests under low-flow conditions, $\mathrm{PT}_{\text {low, }}$ and high-flow conditions, $\mathrm{PT}_{\text {high, of Prairie }}$ Creek, Nebraska, USA, at the test site 
Fig. 2 Prairie Creek test site in Nebraska, USA: a site location, $\mathbf{b}$ instrumentation and location of cross section A-A', and c hydrogeologic cross section A-A' (not to scale). The shaded area indicates the active channel and the white arrow indicates direction of streamflow; $x$ and $y$ indicate origin and orientation of the coordinate system of the applied analytical solutions (b). The cross section shows boundaries of the hydrogeologic units, positions of the piezometer screens and the pumping well $(P W)$. Note the location of the piezometers at shallow, intermediate, and deep aquifer depths. Modified from Kollet and Zlotnik (2003)

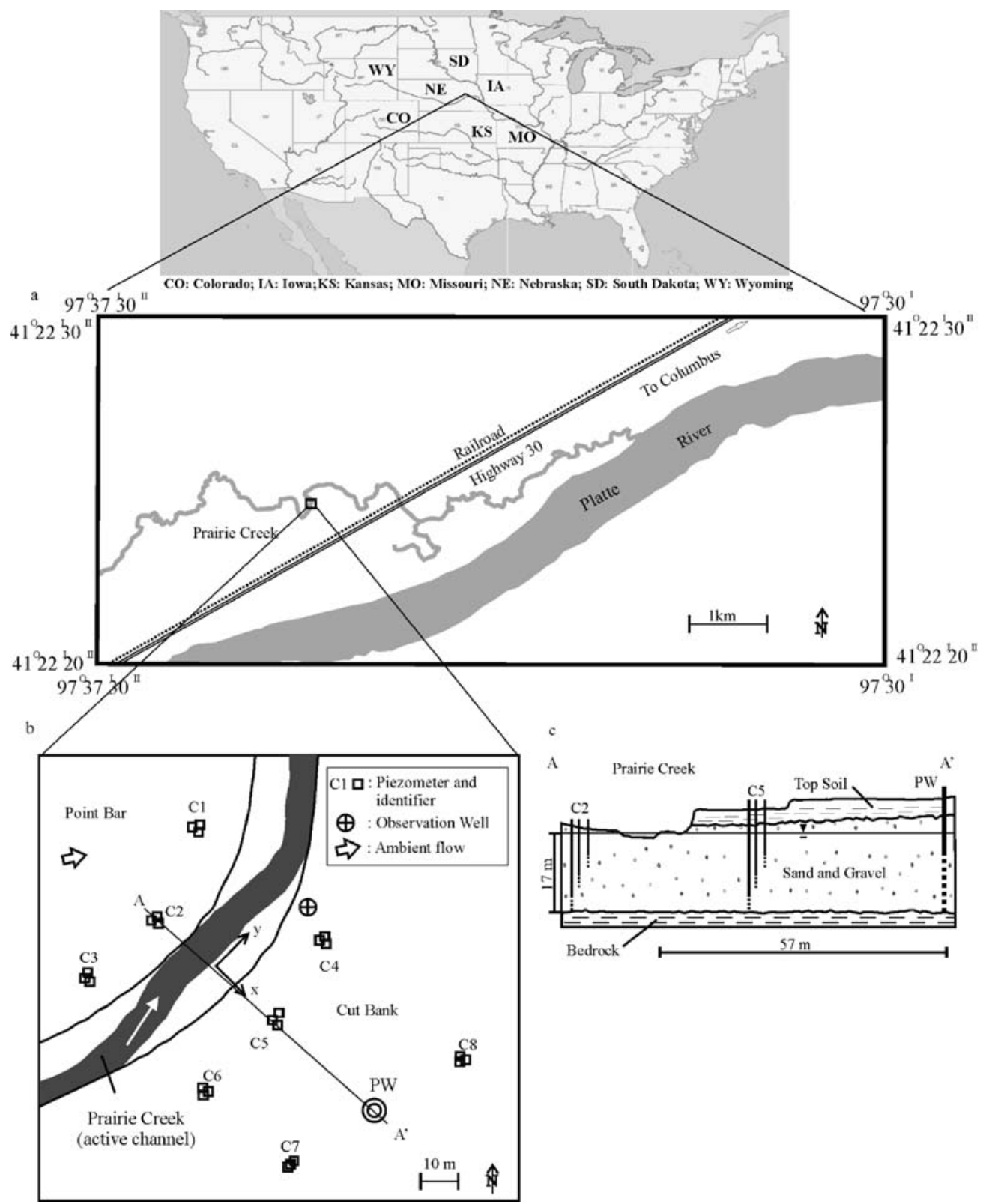

analytical models of pumping-induced stream depletion were based on the image-well theory (Theis 1941; Glover and Balmer 1954). Major assumptions were those of a straight stream that fully penetrates the homogeneous aquifer. Later, Hantush (1965) introduced the concept of streambed conductance that approximates the streamaquifer interface as a layer of uniform thickness and relatively low permeability. This concept was developed more out of mathematical convenience than sedimentologic concepts, but it is still widely applied (Anderson and Woessner 1992). Numerical studies found that the assumption of a fully penetrating stream may lead to an overestimation of stream depletion, and the solutions are highly sensitive to changes in the streambed conductance coefficient (e.g., Sophocleous et al. 1995; Conrad and Beljin 1996). However, no insight was provided in the validity of the streambed conductance concept in streamaquifer models.

Only recently, analytical models were improved to take into account partial stream penetration, a finite stream width, and also large-scale aquifer heterogeneity (Hunt 1999; Zlotnik et al. 1999; Butler et al. 2001). Yet, these two-dimensional models also rely on the application of the streambed conductance concept. A newer model by Hunt (2003) is not applicable in this study, because it is valid for semi-confined or leaky aquifer conditions only and the aquifer in this study is unconfined (Kollet and Zlotnik 2005a).

Simultaneously, with the advent of improved analytical models, results of two well-designed field studies aimed at a field verification of the theory were published (Hunt et al. 2001; Nyholm et al. 2002 and 2003). These studies 
utilized pumping test data and stream discharge measurements for the inverse prediction of stream depletion rates and concluded that stream depletion rates are identifiable, though highly uncertain. These studies were performed along a drain and a small stream with widths of about $2 \mathrm{~m}$ and discharges less than $0.45 \mathrm{~m}^{3} / \mathrm{s}$, far from conditions encountered in many natural stream-aquifer systems. Additionally, the observation networks used were not fully three-dimensional, thus, providing only limited insight into the response of the stream-aquifer system.

In studies of stream-aquifer interactions, water temperature has been used as a tracer to determine the direction of groundwater flow and flow velocities (e.g. Stallman 1965; Lapham 1989; Taniguchi 1993; Silliman and Booth 1993; Constantz et al. 2003; Brewster 2004). However, few studies of stream-aquifer interactions studied the effect of temperature on the kinematic viscosity of the water and, thus, the hydraulic conductivity. Constantz et al. (1994) discussed diurnal temperature effects on seepage rates. That study demonstrated qualitatively that the effect of temperature was the main reason for the variability in daily streamflow losses. Ronan et al. (1998) also studied diurnal fluctuations in seepage rates and included numerical modeling results in their study. Bravo and Jiang (2002) applied a coupled groundwater flow and heat transport model to account for the dependence of water density and viscosity on temperature. Using synthetic and field data, they solved the inverse problem based on head and temperature data. The objective of this study is to examine the validity of the streambed leakage and conductance concept in two-dimensional flow models using drawdown and stream water-temperature data from three pumping tests performed under distinct hydrologic conditions.

\section{Model outline and hydrologic framework}

Hunt (1999) and Butler et al. (2001) presented twodimensional models of stream-aquifer interactions as a correction to the two-dimensional Theis (1935) solution for drawdown in a homogeneous confined aquifer (in the following, these models will be referred to as Hunt and BZT models). This correction can be illustrated by the Hunt model for drawdown, $s(x, y, t)$, as

$$
\begin{aligned}
s(x, y, t)= & \frac{Q}{4 \pi T}\left\{E_{1}\left[\frac{(\ell-x)^{2}+y^{2}}{4 T t / S}\right]\right. \\
& \left.-\int_{0}^{\infty} e^{-\theta} E_{1}\left[\frac{(\ell+|x|+2 T \theta / \lambda)^{2}+y^{2}}{4 T t / S}\right] d \theta\right\}, \\
& (-\infty<x>\infty,-\infty<y>\infty, 0<t>\infty)
\end{aligned}
$$

On the right-hand side of Eq. (1), the first term is the Theis (1935) solution for drawdown in a confined aquifer and the second term describes the streambed leakage; $x, y$ $(\mathrm{L})$ are Cartesian coordinates; $t(\mathrm{~T})$ is time; $Q\left(\mathrm{~L}^{3} / \mathrm{T}\right)$ is the pumping rate; $T=K b\left(\mathrm{~L}^{2} / \mathrm{T}\right)$ is the transmissivity; $K(\mathrm{~L} / \mathrm{T})$ is the hydraulic conductivity; $b(\mathrm{~L})$ is the saturated aquifer thickness; $S(-)$ is the aquifer storativity; $\ell$ (L) is the distance between the pumping well and stream (located along the $y$-axis); $\lambda(\mathrm{L} / \mathrm{T})$ is the streambed conductance coefficient; and $\theta$ is the dummy variable of integration. In this study, the term aquifer storativity refers to the specific yield of the aquifer material, because the models were applied only to the late time drawdown data (e.g. Neuman 1972).

Generally, $\lambda$ may be approximated as

$\lambda \approx\left(W K^{\prime}\right) / m^{\prime}$

where $W(\mathrm{~L})$ is the average stream width, $K^{\prime}(\mathrm{L} / \mathrm{T})$ is the hydraulic conductivity, and $m^{\prime}(\mathrm{L})$ is thickness of the streambed sediments (Hunt et al. 2001; Zlotnik 2004). Note that the presence of a "low conductivity streambed layer" $\left(K^{\prime}<<K\right)$ is essential for the validity of the models, because this layer facilitates the partially penetrating stream, while applying the Dupuit assumptions.

Equation (1) states that deviations in measured drawdown from the Theis (1935) solution caused by the presence of a stream may be readily quantified via the streambed leakage term. The practical validity of this solution may be tested by applying Eq. (1) to pumping test data collected in the absence and presence of a stream using identical monitoring networks and appropriate boundary conditions. Aquifer parameter estimates such as the transmissivity $T$ and storativity $S$, must be identical under both hydrologic conditions.

Unfortunately, it is not possible to simply "turn on" and "turn off" a stream, especially under natural flow conditions, in order to perform the two pumping tests. Artificial test settings such as pumping tests along engineered ditches, may be seen as an alternative, yet they cannot serve as a substitute for studies of real-world stream-aquifer systems.

During the time period 1999-2001, a climatic opportunity emerged in the Platte River watershed, east-central Nebraska, USA, to perform pumping tests under distinct hydrologic conditions. Because of variable weather conditions, the meandering Prairie Creek near Columbus, Nebraska underwent transitions from low stream discharge (May 2000) to completely dry conditions (August 2000 ) and to relatively high stream discharge (June 2001). Figure 1 shows the stream discharge curves during the pumping test $\mathrm{PT}_{\text {low }}$ that was started in May 2000 and $\mathrm{PT}_{\text {high }}$ that was started in June 2001. The stream discharge was estimated utilizing the velocity-area concept and the velocities were measured using the 6/10th method (Rantz and others 1982).

The specific objectives of this study are to test the hypotheses that (1) the streambed leakage term accounts for a partially penetrating stream; and (2) the streambed conductance coefficient $\lambda$ accounts for the average stream width and a streambed hydraulic conductivity and thickness. These hypotheses are tested by comparing the 
results from the analysis of the pumping tests under noflow and flow conditions of the stream and varying stream width.

Because the temperature of the infiltrating stream water was higher than the groundwater temperature, stream water temperature was monitored to assess the effect of the temperature on the hydraulic conductivity and possible impact on the analysis results. Note that two of the pumping tests have been partially analyzed and discussed previously. The pumping test under low-flow conditions was analyzed using the aforementioned two-dimensional analytical models of stream-aquifer interactions (Kollet and Zlotnik 2003). The test under no-flow conditions was analyzed using three-dimensional analytical and numerical models for aquifer heterogeneity interpretation (Kollet and Zlotnik 2005b). The study presented here provides a unique systematic analysis of stream-aquifer interactions under pumping and distinct hydrologic conditions.

\section{The Prairie Creek test site and performance of pumping tests}

The Prairie Creek test site is located along the naturally meandering Prairie Creek, Platte River watershed, eastcentral Nebraska, USA (Fig. 2). Prairie Creek is very shallow; the stream penetrates less than $5 \%$ of the saturated thickness of the underlying aquifer. The stream discharge is highly variable $\left(0-50 \mathrm{~m}^{3} / \mathrm{s}\right.$ under drought and spring runoff conditions). The width of Prairie Creek reaches approximately $25 \mathrm{~m}$ under bankfull flow. At the site, the unconfined aquifer has an average saturated thickness of about $17 \mathrm{~m}$ and consists of poorly sorted fine to coarse sand and gravel. The sediments are associated with the braided river depositional environment from paleochannels of the Platte River.

A high-capacity pumping well and eight piezometer clusters are present at the site. Each cluster contains three piezometers screened at shallow, intermediate, and deep aquifer depths. The completion depths of the piezometers in each cluster are indicated with the suffixes ' $s$ ' for shallow, ' $\mathrm{i}$ ' for intermediate, and 'd' for deep (e.g., C1s: shallow piezometer of cluster 1). The pumping well is completed at the aquifer base at a depth of about $19.5 \mathrm{~m}$ with a casing diameter of $40 \mathrm{~cm}$ at a distance of $57 \mathrm{~m}$ from the stream. The screened interval extends from about 4.9 to $19.5 \mathrm{~m}$ aquifer depth and covers more than $80 \%$ of the saturated aquifer thickness under non-pumping conditions.

Three long-term pumping tests were performed at the Prairie Creek test site under distinct hydrologic conditions (Table 1). The test under low stream discharge conditions $\left(\mathrm{PT}_{\text {low }}\right)$ continued for 144 hours. The test under high stream discharge conditions and almost bankfull flow of Prairie Creek $\left(\mathrm{PT}_{\text {high }}\right)$ continued for 147 hours. During these tests, the pumped water was discharged back into the flowing stream at a distance of about $300 \mathrm{~m}$ downstream from the test site. Note the difference in the stream widths between the $\mathrm{PT}_{\text {low }}$ and $\mathrm{PT}_{\text {high }}$ tests. The test under dry stream conditions (PT) continued for 72 hours.
Table 1 Summary of pumping test characteristics at the Prairie Creek site

\begin{tabular}{llll}
\hline Pumping test characteristics & $\mathrm{PT}$ & $\mathrm{PT}_{\text {low }}$ & $\mathrm{PT}_{\text {high }}$ \\
\hline Starting date & $08 / 08 / 2000$ & $30 / 05 / 2000$ & $01 / 06 / 2001$ \\
$\begin{array}{l}\text { Duration (hours) } \\
\text { Pumping rate }\left(\mathrm{m}^{3} / \text { day) }\right.\end{array}$ & 72 & 144 & 147 \\
$\begin{array}{l}\text { Mean stream discharge } \\
\left(\mathrm{m}^{3} / \mathrm{s}\right)\end{array}$ & 0.0 & 6,480 & 6,480 \\
\begin{tabular}{l} 
Stream width $(\mathrm{m})$ \\
\hline
\end{tabular} & 0.0 & 0.25 & 1.65 \\
& & & 20 \\
\hline
\end{tabular}

This notation, $\mathrm{PT}_{\text {low }}, \mathrm{PT}_{\text {high }}$, and $\mathrm{PT}$, will be used consistently in the ensuing analysis and discussion.

Before and during the three pumping tests, hydraulic head was monitored via pressure sensors in a number of piezometers (PT: C2s,i,d; C3s,i,d; C4s,i,d; C5s,i,d; $\mathrm{PT}_{\text {low }}$ : C2s,i,d; C4s,i,d; C5s,i,d; PT ${ }_{\text {high }}$ : C2s,i; C3s,i; C4s,i; C5s,i; $\mathrm{C} 6 \mathrm{~s}, \mathrm{i} ; \mathrm{C} 7 \mathrm{~s}, \mathrm{i} ; \mathrm{C} 8 \mathrm{~s}, \mathrm{i})$. In the remaining piezometers, hydraulic head measurements were taken manually. Water-level data collected before the start of pumping were used to derive the ambient groundwater flow direction that is indicated with the arrows in Fig. 2. The general direction did not change significantly among the different tests. Data from permanent and temporary piezometers in the stream showed that the stream reach at the site was initially under losing and gaining conditions for the tests $\mathrm{PT}_{\text {low }}$ and $\mathrm{PT}_{\text {high }}$, respectively. It cannot be excluded, however, that during $\mathrm{PT}_{\text {low }}$ and $\mathrm{PT}_{\text {high }}$, there were also gaining and losing areas along the streambed, respectively, because of small scale heterogeneity near the stream-aquifer interface. Because the applied governing equations are linear and based on the superposition principle, drawdowns can be calculated regardless of whether different portions of the stream are gaining or losing water. Data collected during the actual tests indicate that the water table adjacent to the stream edge never dropped below the streambed. Thus, the stream was always in direct hydraulic connection with the aquifer during the $\mathrm{PT}_{\text {low }}$ and $\mathrm{PT}_{\text {high }}$ tests.

\section{Time-drawdown data and analysis}

Examples of time-drawdown curves measured in the shallow, intermediate, and deep piezometers of cluster $\mathrm{C} 2$ at the point bar and cluster $\mathrm{C} 5$ at the cut bank are shown in Fig. 3. The measured time-drawdown behavior is characteristic of unconfined aquifers and exhibits the three distinct drawdown phases that are attributed to the interaction of compressible aquifer storage and the vertical movement of the free water-table surface in the unconfined aquifer (Neuman 1972 and 1974).

Comparison of the curves shows that the drawdowns up to $200 \mathrm{~min}$ ( $\sim 0.1$ day) of pumping are similar because water is mainly released from compressible aquifer storage. At cluster $\mathrm{C} 5$, differences at very early times ( $\sim 0.01$ day) are caused by fluctuations of the water column in the piezometer that are not resolved enough, because of the relatively large measurement interval of 
Fig. 3 Drawdown in the piezometers of the clusters $\mathrm{C} 2$ and $\mathrm{C} 5$ during the pumping tests PT, $\mathrm{PT}_{\text {low }}$, and $\mathrm{PT}_{\text {high }}$. $s$ shallow; $i$ intermediate; and $d$ deep
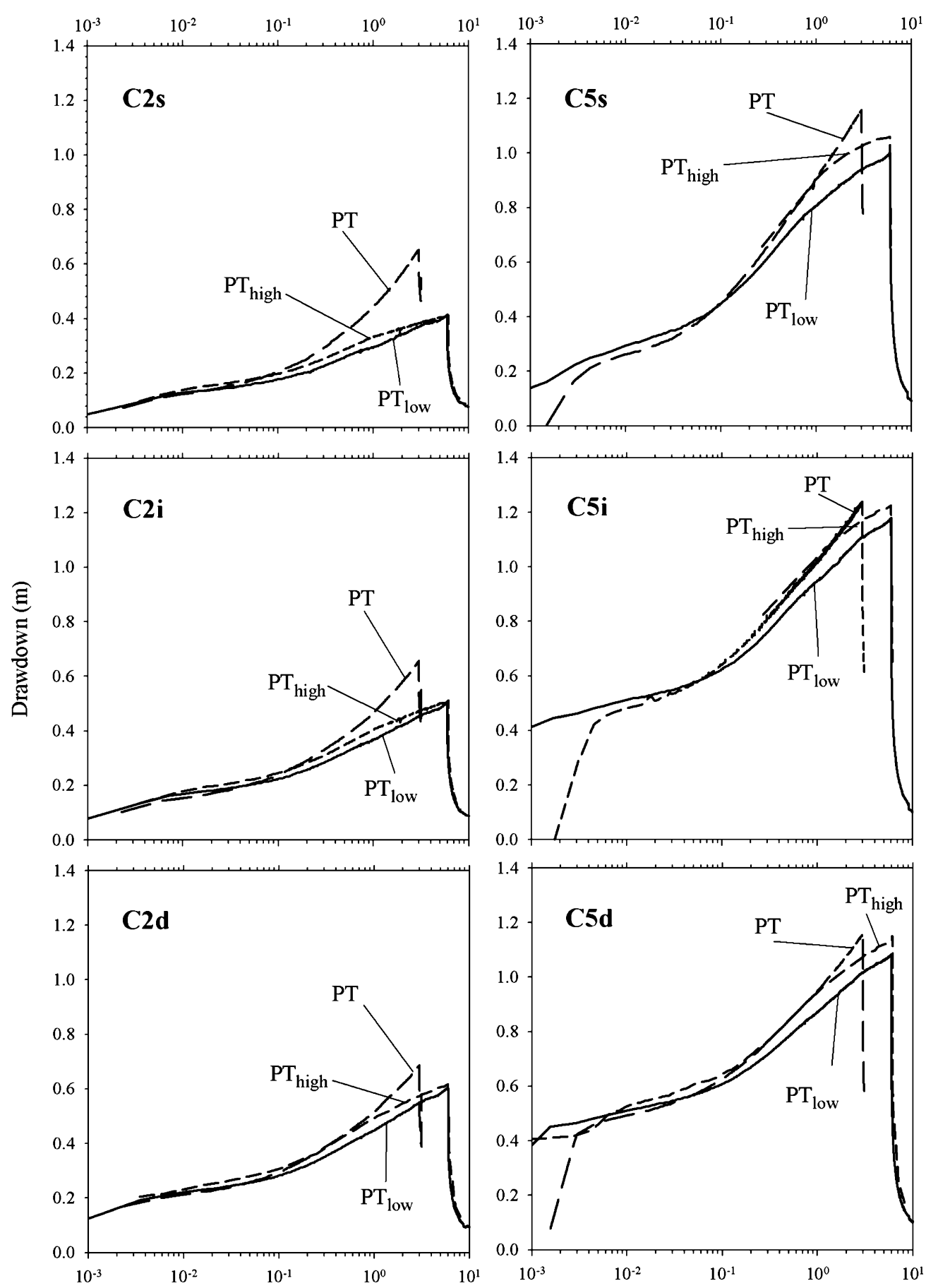

Time (days)
2 min. With continuing pumping, the boundary condition at the stream and induced seepage become important. As expected, maximum drawdown is observed during PT for large time periods. The differences in the drawdown magnitudes between the test without streamflow, PT, and both tests with streamflow, $\mathrm{PT}_{\text {low }}$ and $\mathrm{PT}_{\text {high }}$, are mainly caused by seepage from the stream.

Comparison of data from $\mathrm{PT}_{\text {low }}$ and $\mathrm{PT}_{\text {high }}$ indicates that slightly larger drawdown was observed under highflow conditions at Prairie Creek. This observation is not intuitive, because one would expect increased seepage rates under higher flow stages and larger stream widths, which, in turn, reduce drawdown in the aquifer (Eqs. 1 and 2). Possible explanations for this drawdown behavior are provided in the Discussion section. For large times, the discrepancies in drawdown between $\mathrm{PT}_{\text {low }}$ and $\mathrm{PT}_{\text {high }}$ diminish notably.

Water-table recovery after pumping cessation was monitored over a relatively short time period compared to the pumping duration. Recovery phases of $\mathrm{PT}_{\text {low }}$ and 
Table 2 Constants used in inverse modeling of pumping test data

\begin{tabular}{lllll}
\hline Test & \multicolumn{3}{l}{ Constants (input) } & \\
\cline { 2 - 5 } & $Q\left(\mathrm{~m}^{3} /\right.$ day $)$ & $W(\mathrm{~m})$ & $\ell(\mathrm{m})$ & $b(\mathrm{~m})$ \\
\hline $\mathrm{PT}_{\text {low }}$ & 6,480 & 10 & 57 & 16.9 \\
$\mathrm{PT}$ & 6,480 & NA & NA & 17.0 \\
$\mathrm{PT}_{\text {high }}$ & 6,480 & 20 & 47 & 17.2 \\
\hline
\end{tabular}

$Q$ pumping rate; $W$ stream width; $\ell$ distance between the pumping well and the stream; $b$ aquifer thickness; NA not applicable

$\mathrm{PT}_{\text {high }}$ show identical behavior. The early recovery phase of PT reveals qualitatively similar behavior. Note that recovery data were not utilized in the analysis because of unknown backflow into the well from the discharge pipes immediately after pumping cessation (no check-valve was used during the pumping tests).

For the analysis using two-dimensional analytical models that are based on the Dupuit assumptions, the data collected in the piezometers of the three-dimensional monitoring network were vertically averaged at the individual clusters $\mathrm{C} 1-\mathrm{C} 8$ (see approach by Kollet et al. 2002). This averaging resulted in eight depth-averaged time-drawdown curves, one for each cluster. In this study, the entire drawdown data from all piezometer clusters were analyzed simultaneously for the all three pumping tests (global cluster analysis). This type of analysis yields a single parameter vector.

\section{Parameter identification}

Data analysis was performed via inverse modeling using two-dimensional models. All models were applied to the late time-drawdown data ( $t>1.25$ days), when elastic storage effects cease and the vertical velocity of the declining water table becomes negligible.

Table 2 contains the constants that were used in the analysis to determine the hydraulic properties of the aquifer and the hypothetical streambed. The Hunt model of a homogeneous aquifer was used for interpreting the two-dimensional vertically averaged time-drawdown data. Minor variations of the saturated thickness $b$ between the different tests were taken into account in determining the transmissivity values. Therefore, three fitting parameters were used to reproduce the observed drawdown in the case of $\mathrm{PT}_{\text {low }}$ and $\mathrm{PT}_{\text {high }}$ : the hydraulic conductivity, $K$, the aquifer storativity, $S$, and streambed conductance, $\lambda$, per unit stream length. In the case of the PT test in the absence of flow in Prairie Creek, the Theis (1935) model was used, and the number of fitting parameters reduces to two, namely $K$ and $S$.

The BZT model (Butler et al. 2001) was used in the global cluster analysis for simulating a piecewise-homogeneous aquifer that accounts for the meandering stream architecture of the modern Prairie Creek deposits. In the BZT model, the aquifer consists of three parallel, infinite strips: one underneath the stream and one for each stream bank. The stream banks in the model are named cut bank and point bar, which is consistent with the sedimentology at the site. The model assumes uniformity in $S$ and a piecewise-uniform distribution of $K$ from the point bar to the cut bank in an aquifer of infinite extent. In the applied BZT model, the point bar has a uniform but different hydraulic conductivity than the cut bank, because it consists of reworked and re-deposited alluvium of Prairie Creek, which migrates laterally due to the erosional and depositional process along the channel (Allen 1970). The resulting parameter vector includes four parameters: $K_{\text {point bar, }}, K_{\text {cut bank }}, \lambda$, and $S$. The details on the application of piecewise-homogeneous aquifer model are provided in Kollet and Zlotnik (2003).

For nonlinear parameter optimization, the software package PEST2000 (Doherty 1994), which utilizes a Gauss-Marquardt-Levenberg algorithm, was linked to the analytical models. This algorithm minimizes the sum of equally weighted squared differences (residuals) between calculated and measured data. The logarithmic transformation of the parameter vectors was used for improvement of convergence (Hill 1998). Consecutive runs with varying initial parameter guesses were performed to test whether the global minimum of the sum of squared residuals function was reached.

\section{Results of time-drawdown data analysis}

In this section, the results from the drawdown data analysis are provided using the entire data set from all eight piezometer clusters simultaneously. Confidence limits, parameter correlation, and sensitivities, which would be beyond the scope of this study, have been discussed by Christensen (2000), Nyholm et al. (2002), and specifically, for the stream-aquifer system under investigation, by Kollet and Zlotnik (2003).

Table 3 Parameter estimates from the global cluster analyses (GCA) using the Hunt model (homogeneous aquifer) and BZT model (piecewise-homogeneous aquifer)

\begin{tabular}{|c|c|c|c|c|c|c|c|c|c|}
\hline \multirow[t]{2}{*}{ Applied model } & & \multicolumn{3}{|c|}{$K$ (m/day) } & \multicolumn{3}{|l|}{$S(-)$} & \multicolumn{2}{|c|}{$\lambda$ (m/day) } \\
\hline & & $\overline{\mathrm{PT}}$ & $\mathrm{PT}_{\text {low }}$ & $\mathrm{PT}_{\text {high }}$ & $\overline{\mathrm{PT}}$ & $\mathrm{PT}_{\text {low }}$ & $\mathrm{PT}_{\text {high }}$ & $\overline{\mathrm{PT}_{\text {low }}}$ & $\mathrm{PT}_{\text {high }}$ \\
\hline Homogeneous & & 96 & 93 & 85 & 0.19 & 0.16 & 0.19 & 18.6 & 14.2 \\
\hline Piecewise- & Point bar & 34 & 21 & 31 & & & & & \\
\hline Homogeneous & Cut bank & 108 & 115 & 107 & 0.29 & 0.14 & 0.11 & 22.5 & 21.9 \\
\hline
\end{tabular}

$K$ aquifer hydraulic conductivity; $S$ aquifer storativity; $\lambda$ streambed conductance coefficient 
Global cluster analysis, GCA

The parameter estimates from the simultaneous analysis of the entire data set are summarized in Table 3. The results of the GCA from all three tests $\mathrm{PT}_{\text {low }}, \mathrm{PT}$, and $\mathrm{PT}_{\text {high }}$ agree very well. Arithmetic mean values of the different parameters from the GCA results are as follows: $K \approx 92 \mathrm{~m} /$ day, $S \approx 0.178$, and $\lambda \approx 16 \mathrm{~m} /$ day. However, measured versus calculated data plots (Fig. 4) revealed a low degree of goodness of fit caused by trends in the data matches (overestimation of the slope of the late timedrawdown curves).

An effort was made to consider large-scale aquifer heterogeneity using the BZT model of a piecewisehomogeneous aquifer (for details see Kollet and Zlotnik 2003). It can be argued that because of different depositional and erosional processes at the cut bank and point bar (meandering stream), differences are present in the hydrostratigraphy on a larger scale that might affect
Fig. 4 Measured versus calculated drawdown of the three pumping tests $\mathrm{PT}, \mathrm{PT}_{\text {low }}$, and $\mathrm{PT}_{\text {high }}$ from the global cluster analysis using the a homogeneous and $\mathbf{b}$ piecewise-homogeneous aquifer model a
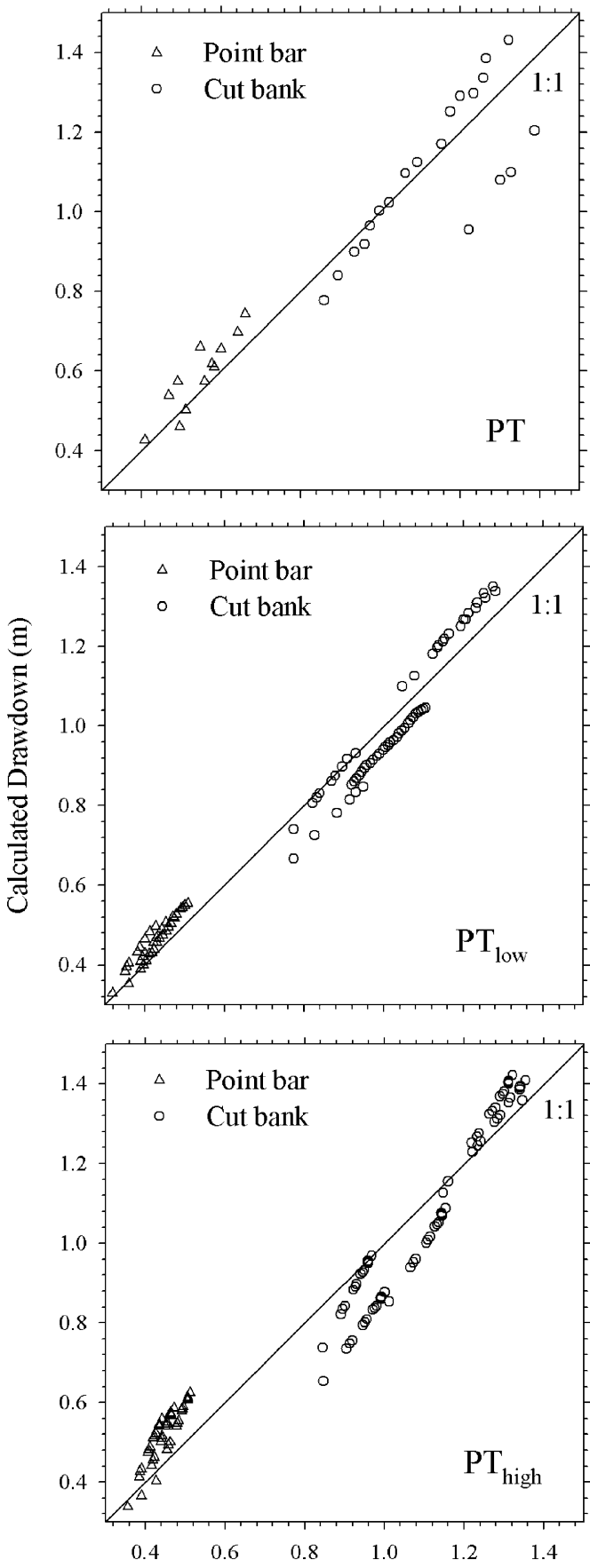

Measured Drawdown (m)

\section{b Piecewise-Homogeneous}
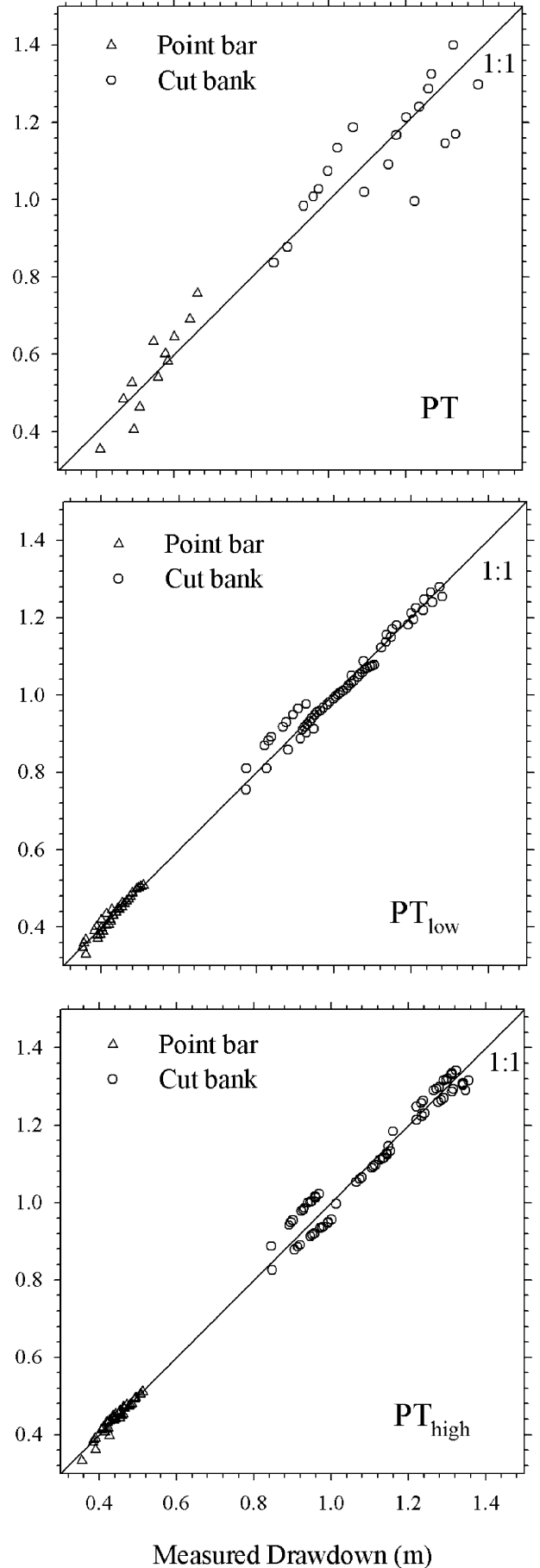
drawdown at the observation locations (Allen 1970). The aquifer was, therefore, divided into two sub-regions representing the point bar and the cut bank individually. Application of the sedimentologic rationale of the meandering stream architecture to the data of the different tests $\left(\mathrm{PT}_{\text {low }}, \mathrm{PT}\right.$, and $\left.\mathrm{PT}_{\text {high }}\right)$ resulted in excellent agreement in $K_{\text {cut bank }} \approx 110 \mathrm{~m} /$ day, $K_{\text {point bar }} \approx 29 \mathrm{~m} /$ day, and $\lambda \approx$ $22 \mathrm{~m} /$ day. The $K_{\text {point bar }}$ estimates are in the bounds of the slug-test results from the point bar (Kollet and Zlotnik $2005 \mathrm{a}, \mathrm{b})$, though appear to be at the lower end of the distribution. The storativity value obtained from PT is $S=$ 0.29 compared to $S \approx 0.125$ from the $\mathrm{PT}_{\text {low }}$ and $\mathrm{PT}_{\text {high }}$ tests (Table 3).

In Fig. 4, the measured versus calculated data plots obtained from the analysis using the piecewise-homogenous aquifer model show a strong improvement in the curve fits for the tests $\mathrm{PT}_{\text {low }}$ and $\mathrm{PT}_{\text {high }}$, and basically no improvement for the PT test when compared to the results obtained with the homogeneous aquifer model.

\section{Discussion}

The results from the analyses of $\mathrm{PT}_{\text {low }}$ and $\mathrm{PT}_{\text {high }}$ with the two-dimensional models of stream-aquifer interactions show that the uniform aquifer model provides relatively consistent parameter estimates. It appears that simultaneous use of all data (global analysis) provides a good agreement of results from the analysis of the data from the different pumping tests under varying hydrologic conditions. The agreement of $K$ and $S$ obtained from global analyses using the two-dimensional Hunt and BZT models (Table 3) suggests the validity of the streambed leakage concept. However, the stream width between the test $\mathrm{PT}_{\text {low }}$ and $\mathrm{PT}_{\text {high }}$ increased two-fold in the field (Table 1), which should result in a two-fold increase in the streambed conductance coefficient $\lambda=\left(W K^{\prime}\right) / m^{\prime}$ in the analysis. This is not the case, though; $\lambda$ decreases slightly in the interpretation of the test $\mathrm{PT}_{\text {high }}$. The reason for this decrease in $\lambda$ is the slight increase in the measured drawdown during $\mathrm{PT}_{\text {high. }}$ This result is inconsistent with the rational that a wider stream causes larger seepage rates and, thus, smaller drawdown in the aquifer. In the following, focus will be placed on two possible explanations for this inconsistency in observed drawdown between $\mathrm{PT}_{\text {low }}$ and $\mathrm{PT}_{\text {high }}$ : (1) the effect of temperature on the hydraulic conductivity due to infiltration of warmer stream water into the aquifer; (2) changes in the hydraulic streambed properties, because of erosional and depositional processes as the bed adjusts to varying stream stages, i.e., a dynamic streambed.

The temperature effect necessitates much higher temperatures of the infiltrating stream water during $\mathrm{PT}_{\text {low }}$ compared to $\mathrm{PT}_{\text {high }}$ to compensate for the doubling in the stream width. However, the collected stream watertemperature data do not exhibit such a difference. Although there are differences of more than $10^{\circ} \mathrm{C}$ in peak temperature values over short time periods, the

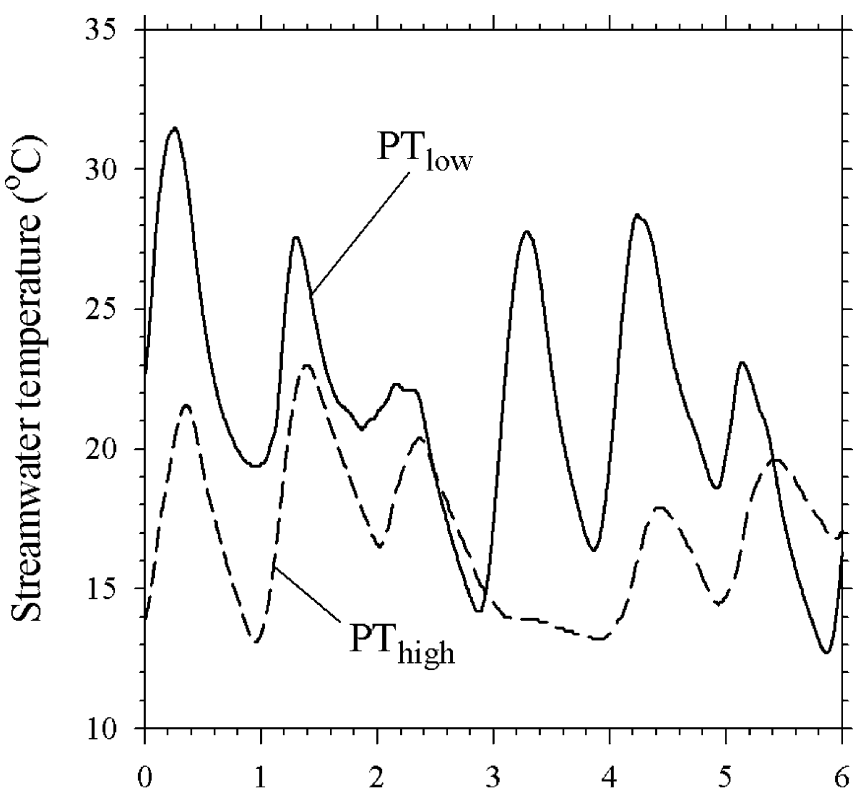

\section{Days of pumping}

Fig. 5 Streamwater temperatures during the pumping tests $\mathrm{PT}_{\text {low }}$ and $\mathrm{PT}_{\text {high }}$

average temperature difference is only about $3^{\circ} \mathrm{C}$ over the course of the tests (Fig. 5, Table 4). This low average temperature difference and associated change in the streambed hydraulic conductivity cannot account for a doubling in the stream width in $\lambda=\left(W K^{\prime}\right) / m^{\prime}$, if a constant streambed thickness $m^{\prime}$ is assumed. Therefore, the second explanation dealing with a dynamic streambed is explored further below.

The analysis of the pumping test data using analytical models is based on the major assumption that the streambed sediments were the same among the different tests, which implies a non-dynamic streambed. This assumption is violated even under small changes in the stream stage, which cause an immediate adjustment of the bed topography - erosion and deposition during rising and falling stream stage, respectively (e.g., Bridge 1977). The stream stage during $\mathrm{PT}_{\text {high }}$ was larger compared to the stage during $\mathrm{PT}_{\text {low, }}$, which caused considerable erosion and ensuing re-deposition of sediments in the stream channel. Therefore, the assumption of the streambed being the same sedimentary body during both tests is doubtful. However, the question arises, whether the sediments that were exposed by erosion or re-deposited before and

Table 4 Statistics of streamwater temperature during pumping tests $\mathrm{PT}_{\text {low }}$ and $\mathrm{PT}_{\text {high }}$

\begin{tabular}{llllll}
\hline Test & Number of points & \multicolumn{5}{l}{ Temperature $\left({ }^{\circ} \mathrm{C}\right)$} \\
\cline { 3 - 6 } & & Mean & Min & Max & CV \\
\hline $\mathrm{PT}_{\text {low }}$ & 4,321 & 21.5 & 12.7 & 31.5 & 0.20 \\
$\mathrm{PT}_{\text {high }}$ & 1,874 & 17.9 & 13.1 & 23.0 & 0.16 \\
\hline
\end{tabular}

The coefficient of variation, $\mathrm{CV}$, is defined as the ration between the standard deviation and the mean 
during $\mathrm{PT}_{\text {high }}$ were significantly different compared to $\mathrm{PT}_{\text {low. }}$ Visual inspection and comparison of the streambed during $\mathrm{PT}_{\text {low }}$ and a dry period after $\mathrm{PT}_{\text {high }}$ did not show significant mud draping, armoring, or any other major differences. This result is obvious, because the composition of the sediments derived from the source areas and transported by the river did not change between the different tests. However, it cannot be excluded that the streambed sediments right at the stream-aquifer interface were different enough during $\mathrm{PT}_{\text {low }}$ and $\mathrm{PT}_{\text {high }}$ to produce a significant difference in $K^{\prime}$ between the two different tests. After eliminating temperature as the major reason for the inconsistency in drawdown and $\lambda$ estimates between $\mathrm{PT}_{\text {low }}$ and $\mathrm{PT}_{\text {high }}$, changes in streambed sediments and, thus, the hydraulic connection between the stream and the aquifer appear to be one likely explanation. Unfortunately, there is no field data to corroborate this rationale at the Prairie Creek test site, but the principles used here are well known and commonly applied in sedimentology (Allen 1970; Bridge and Jarvis 1976; Fraser and Davis 1998).

It is instructive to check the magnitude of $\lambda$ using independent estimates of characteristic parameters at the site. Experimental data of Cardenas and Zlotnik (2003), which were collected in the summer of the year 2000, yielded $K^{\prime}=15-20 \mathrm{~m} /$ day using various averaging techniques for hydraulic conductivity of the streambed sediments from constant-head injection tests. They also proposed to use the depths of scour surfaces as a proxy for the streambed thickness $m^{\prime}$; estimates of this value from ground-penetrating radar surveys indicate that $m^{\prime}$ varies between 2 and $3 \mathrm{~m}$. With the stream width $W$ varying between 10 and $20 \mathrm{~m}$ (Table 1 ), an estimate of $\lambda=$ $\left(W K^{\prime}\right) / m^{\prime}$ yields values between 60 and $100 \mathrm{~m} /$ day. These values exceed $\lambda$ estimates from inverse modeling, which are summarized in Table 3, by a factor greater than 3 . Thus, there is a significant overestimation in independently determined $\lambda$ values from upscaled small-scale hydraulic test results compared to values inferred from pumping test data analysis, which may result in a $100 \%$ difference in seepage rate estimates.

The effect of possible large-scale aquifer heterogeneity in the hydraulic conductivity was also demonstrated in this study following the approach by Kollet and Zlotnik (2003). By using a two-dimensional approximation of the point bar-cut bank hydrostratigraphy, which resulted in a simple piecewise-homogeneous model of the meandering stream architecture, better matches were obtained between the measured and calculated data for the $\mathrm{PT}_{\text {low }}$ and $\mathrm{PT}_{\text {high }}$ tests. However, the analysis of PT without stream discharge using the piecewise-homogeneous model did not improve the data match and resulted in much larger storativity estimates compared to the results from $\mathrm{PT}_{\text {low }}$ and $\mathrm{PT}_{\text {high }}$ (Fig. 4 and Table 3). Thus, the interpretation of the PT pumping test under dry stream conditions requires further discussion.

Prior to the PT test, the stream was completely dry over several weeks and the water table was about $10-20 \mathrm{~cm}$ below the streambed at the site. During PT, the pumped water was discharged back into the dry stream channel at a distance greater than $200 \mathrm{~m}$ downstream from the site. Kollet and Zlotnik (2005a,b) showed that re-infiltration and resulting aquifer return flow was likely during the pumping test and studied the effect on parameter estimates. They used three-dimensional analytical (e.g., Neuman 1974) and numerical models in their analysis of PT. Their estimates of the hydraulic conductivity $(K \approx 100 \mathrm{~m} /$ day) agree well when compared to results in the section Results of time-drawdown data analysis, despite that simpler two-dimensional models were used in this study. In the case of PT, aquifer return flow had the largest effect on $S$ estimates. Analysis of the data using models without aquifer return flow arrived at storativity estimates of $S \approx 0.3$ compared to $S \approx 0.12$ using models that incorporate aquifer return flow. From these results, it is concluded that aquifer return flow is the major reason for larger storativity estimates from PT test in this study. Incorporation of aquifer return flow resulted in maximum increase in the $K$ estimates of some $15 \%$, which suggest that neglecting this process in the analysis using twodimensional models does not have a major effect on the $K$ estimates and does not change the results and conclusions of this study. Note that shallow aquifer return flow cannot be approximated in the two-dimensional analytical models applied in this study, because these models are based on depth-averaged drawdown.

\section{Summary and conclusions}

Interpretation of a drawdown and temperature data set from three pumping tests performed at the Prairie Creek site provides insight into the validity of the streambed conductance concept as an integral characteristic for streambed properties and geometry. Three pumping tests were performed under different hydrologic conditions: high stream discharge $\left(\mathrm{PT}_{\text {high }}\right)$, low stream discharge $\left(\mathrm{PT}_{\text {low }}\right)$, and under drought conditions without stream discharge (PT). Analyses of the unique data set allows for the testing of the streambed leakage term in the Hunt and BZT models, which reduce to the Theis (1935) solution in absence of a stream. Comparison of the time-drawdown data from the $\mathrm{PT}_{\text {low }}$ and $\mathrm{PT}_{\text {high }}$ tests with the $\mathrm{PT}$ test indicates that the effect of the shallowly penetrating stream on drawdown responses is clearly detectable. Anomalies in drawdown responses between $\mathrm{PT}_{\text {low }}$ and $\mathrm{PT}_{\text {high }}$ (drawdown is generally larger when there is a larger stream width during $\mathrm{PT}_{\text {high }}$ ) may be caused by the dynamics of the streambed (erosion and deposition). This result is directly reflected in the estimates of the conductance coefficient $\lambda$.

Simultaneous (global) analysis of all data from each test shows good agreement between estimates from different tests, but may lead to poor matches between calculated and measured data in individual clusters/ piezometers. Application of a piecewise-homogeneous BZT model implicitly considering the meandering stream architecture of modern stream deposits improves these 
matches, which may suggest large-scale aquifer heterogeneity on the point-bar scale.

The good agreement between the analysis results of the test data in the presence and absence of Prairie Creek, Nebraska, USA suggests the usefulness of the stream approximation in the two-dimensional Hunt and BZT models. However, the large change in the stream width from test $\mathrm{PT}_{\text {low }}$ to test $\mathrm{PT}_{\text {high }}$ was not reflected in estimates of the streambed conductance coefficient $\lambda=$ $\left(W K^{\prime}\right) / m^{\prime}$, because of similar drawdown during $\mathrm{PT}_{\text {high }}$ that occurred despite a two-fold increase in the stream width compared to $\mathrm{PT}_{\text {low. After eliminating temperature effects }}$ as the major reason for this inconsistency, streambed dynamics, i.e., the adjustment of the streambed topography to changes in the stream stage, were discussed as one possible explanation. The study clearly shows that $\lambda$ is not scalable by the stream width $W$ for different hydrologic conditions and apparently does not account for an average streambed hydraulic conductivity and thickness. This result has major implications for stream depletion predictions in hydrologic systems where the stream width strongly depends on the stream discharge.

Acknowledgements This research was supported by the USGS Regional Water Resources Competitive Grants Program grant 1434Hq96Gr02683, 1998-2001; grants from the Central Platte Natural Resources District, Nebraska, 1999-2002; and the Water Center, University of Nebraska-Lincoln. The authors acknowledge D. Woodward, Central Platte Natural Resources District, Nebraska, for assistance with project management and equipment; Bayani Cardenas for assistance in the field and useful discussions; and R.J. Edmison for providing access to the site and equipment for the performance of the pumping tests. We also wish to thank the three reviewers for adding to the quality of this manuscript.

\section{References}

Allen JRL (1970) A quantitative model of grain size and sedimentary structures in lateral deposits. Geol J 7(1):129-146

Anderson MP, Woessner WW (1992) Applied groundwater modeling: simulation of flow and advective transport. Academic Press, San Diego, p 281

Bierkens MFP, Weerts HJT (1994) Block hydraulic conductivity of cross-bedded fluvial sediments. Water Resour Res 30 (10):2665-2678

Bravo HR, Jiang F (2002) Using groundwater temperature data to constrain parameter estimation in a groundwater flow model of a wetland system. Water Resour Res 38(8). DOI 10.1029/ 2000WR000172

Brewster C Jr (2004) Delineating and quantifying ground water discharge zones using streambed temperatures. Ground Water 42(2):243-257

Bridge JS (1977) Flow, bed topography, grain size, and sedimentary structure in open channel bends: a three-dimensional model. Earth Surf Process 2:401-416

Bridge JS, Jarvis J (1976) Flow and sedimentary processes in the meandering river South Esk, Glen Clova, Scotland. Earth Surf Process 1(4):303-336

Butler JJ Jr, Zlotnik VA, Tsou MS (2001) Drawdown and stream depletion produced by pumping in the vicinity of a finite-width stream of shallow penetration. Ground Water 39(5):651-659

Butler JJ Jr, Healey JM, McCall GW, Garnett EJ, Loheide SP II (2002) Hydraulic tests with direct-push equipment. Ground Water 40(1):25-36
Cardenas MB, Zlotnik VA (2003) Three-dimensional model of modern channel bend deposits. Water Resour Res 39(6):1441. DOI 10.1029/2002WR001383

Cardenas MB, Wilson JL, Zlotnik VA (2004) Impact of heterogeneity, bed forms and stream curvature on subchannel hyporheic exchange. Water Resour Res 40, W08307. DOI 10.1029/ 2004WR003008

Christensen S (2000) On the estimation of stream flow depletion parameters by drawdown analysis. Ground Water 38(5):726734

Conrad LP, Beljin MS (1996) Evaluation of an induced infiltration model as applied to glacial aquifer systems. Water Resour Bull Am Water Res Assoc 32(6):1209-1219

Constantz J, Thomas CL, Zellweger G (1994) Influence of diurnal variations in stream temperature on streamflow loss and groundwater recharge. Water Resour Res 30(12):3253-3264

Constantz J, Cox MH, Su GW (2003) Comparison of heat and bromide as ground water tracers near streams. Ground Water 41 (5):647-656

Doherty J (1994) PEST-model-independent parameter estimation. Watermark Computing, Corinda, Australia, p 122

Fraser GS, Davis JM (eds) (1998) Hydrogeologic models of sedimentary aquifers. Society of Sedimentary Geology, Tusla, OK, USA, p 188

Glover RE, Balmer CG (1954) River depletion resulting from pumping a well near a river. EOS Trans AGU 35:468-470

Hantush MS (1965) Wells near streams with semipervious beds. J Geophys Res 70:2829-2838

Harvey JW, Wagner BJ (2000) Quantifying hydrologic interactions between streams and their subsurface hyporheic zones. In: Jones JB, Mulholland PJ (eds) Streams and ground waters. Academic Press, San Diego, CA, USA, pp 3-44

Hill MC (1998) Methods and guidelines for effective model calibration, US Geol Surv Water-Resour Invest Rep 98-4005, p 90

Hirsch RM, Costa JE (2004) US stream flow measurements and data dissemination improve. EOS Trans AGU 85(2):197

Hunt B (1999) Unsteady stream depletion from ground water pumping. Ground Water 37(1):98-102

Hunt B (2003) Unsteady stream depletion when pumping from semi-confined aquifer. J Hydrol Eng 12-19

Hunt B, Weir J, Clausen B (2001) A stream depletion field experiment. Ground Water 39(2):283-289

Kaleris V (1986) Estimation of water exchange between surface water and ground water with two-dimensional ground water models (in German), No. 62, Institute for Water Engineering, Stuttgart University, Germany, pp 137

Kasahara T, Wondzell SM (2003) Geomorphic controls on hyporheic exchange flow in mountain streams. Water Resour Res 39(1):1005. DOI 10.1029/2002WR001386

Kollet SJ, Zlotnik VA (2003) Stream depletion predictions using pumping test data from a heterogeneous stream-aquifer system (a case study from the Great Plains, USA). J Hydrol 281:96-114

Kollet SJ, Zlotnik VA (2005a) Reply to comment by H. Lough, Department of Civil Engineering, University of Canterbury, Christchurch, New Zealand, on the paper "Stream depletion predictions using pumping test data from a heterogeneous stream-aquifer system (a case study from the Great Plains, USA)" by S.J. Kollet and V.A. Zlotnik, 281: 96-114. J Hydrol 313:149-152

Kollet SJ, Zlotnik VA (2005b) Influence of aquifer heterogeneity and return flow on pumping test data interpretation. J Hydrol 300:267-285

Kollet SJ, Zlotnik VA, Woodward D (2002) A field and theoretical study on stream-aquifer interactions under pumping conditions in the Great Plains, Nebraska. Proceedings, July 2002, American Water Res. Assoc., Middleburg, VA, USA, pp 29-34

Lapham WW (1989) Use of temperature profiles beneath steam to determine rates of vertical ground-water flow and vertical hydraulic conductivity. US Geol Surv Water Suppl Pap 2337

McDonald MG, Harbaugh AW (1996) User's documentation for MODFLOW-96, and an update to the US Geological Survey 
modular finite-difference ground-water flow model. US Geol Surv Open-File Rep 96-485

Neuman SP (1972) Theory of flow in unconfined aquifers considering delayed response of the water table. Water Resour Res 8(4):1031-1044

Neuman SP (1974) Effects of partial penetration on flow in unconfined aquifers considering delayed aquifer response. Water Resour Res 10(2):303-312

Nyholm TS, Christensen, Rasmussen KR (2002) Flow depletion in a small stream caused by ground water abstraction from wells. Ground Water 40(4):425-437

Nyholm T, Rasmussen KR, Christensen S (2003) Estimation of stream flow depletion and uncertainty from discharge measurements in a small alluvial stream. J Hydrol 274:129-144

Packman AI, Bencala KE (2000) Modeling surface-subsurface hydrological interactions. In: Jones JB, Mulholland PJ (eds) Streams and ground waters. Academic Press, San Diego CA, pp 45-80

Rantz SE et al (1982) Measurements and computation of streamflow, volume1: measurement of stage and discharge. US Geol SurvWater Suppl Pap 2175

Ritzi RW, Dai Z, Dominic DF, Rubin YN (2004) Spatial correlation of permeability in cross-stratified sediment with hierarchical architecture. Water Resour Res 40(3):W03513. DOI 10.1029/ 2003WR002420

Ronan AD, Prudic DE, Thodal CE, Constantz J (1998) Field study and simulation of diurnal temperature effects of infiltration and variable saturated flow beneath an ephemeral stream. J Hydrol 302:154-172

Silliman SE, Booth DF (1993) Analysis of time series measurements of sediment temperature for identification of gaining and losing portions of Juday Creek, Indiana. J Hydrol 146:131-148

Sophocleous M, Townsend MA, Vogler LD, McClain TJ, Marks ET, Coble GT (1988) Experimental studies in stream-aquifer interaction along the Arkansas River in central Kansas: field testing and analysis. J Hydrol 98:249-273

Sophocleous M, Koussis A, Martin JL, Perkins SP (1995) Evaluation of simplified stream-aquifer depletion models for water rights administration. Ground Water 33(4):579-588

Stallman RW (1965) Steady one-dimensional fluid flow in a semi-finite porous medium with sinusoidal surface temperature. J Geophys Res 70(12):2821-2827

Taniguchi, M. (1993), Evaluation of vetical groundwater fluxes and thermal properties of aquifers based on transient temperature depth profiles, Water Resour Res., 29(7), 2021-2026

Theis CV (1935) The lowering of the piezometric surface and the rate and discharge of a well using ground-water storage. EOS Trans AGU 16:519-524

Theis CV (1941) The effect of a well on the flow of a nearby stream. EOS Trans AGU 22:734-738

Woessner WW (2000) Stream and fluvial plain ground water interactions: rescaling hydrogeologic thought. Ground Water 38 (3):423-429

Zlotnik VA (2004) A concept of maximum stream depletion rate for leaky aquifers in alluvial valleys. Water Resour Res 40(66), W06507. DOI 10.1029/2003WR002932

Zlotnik VA, Huang H Jr, Butler JJ (1999) Evaluation of stream depletion considering finite stream width, shallow penetration, and properties of streambed sediments, In: Proceedings of Water 99, Joint Congress 221-226, Brisbane, Australia, July 1999 